\title{
Serum gastrin concentration affects the self replication rate of the enterochromaffin like cells in the rat stomach
}

\author{
Y Tielemans, J Axelson, F Sundler, G Willems, R Håkanson
}

\begin{abstract}
The influence of antrectomy and antrum exclusion on the enterochromaffin like cell kinetics in the gastric mucosa of the rat was studied using a combination of histamine immunocytochemistry and autoradiography after in vivo labelling with tritiated thymidine. In all experimental groups, the enterochromaffin like cells were found to incorporate the DNA precursor, thus indicating an ability to divide. The serum gastrin concentration was raised by antrum exclusion and reduced by antrectomy. After antrum exclusion, the enterochromaffin like cell proliferation rate increased as indicated by a doubling of the labelling index and by the resulting enterochromaffin like cell hyperplasia (after six weeks). After antrectomy, the enterochromaffin like cell labelling index decreased to reach $25 \%$ of the control value; at this time the enterochromaffin like cell density had not decreased significantly. The observed correlation between the enterochromaffin like cell labelling indices and the serum gastrin concentration supports the hypothesis that enterochromaffin like cell proliferation is influenced by serum gastrin.
\end{abstract}

The association of gastric enterochromaffin like cell hyperplasia and prolonged hypergastrinaemia has been shown in $\operatorname{man}^{1-6}$ and in experimental animals. ${ }^{7-10}$ Indeed, patients with atrophic gastritis ${ }^{1-4}$ or with gastrinoma

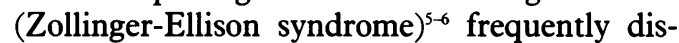
play an increased number of enterochromaffin like cells and at times even enterochromaffin like cell tumours (gastric carcinoids). An analogous increase in the enterochromaffin like cell number has been observed in experimental animals in response to sustained hypergastrinaemia after long term treatment with potent antisecretagogues ${ }^{8-10}$ or after antrum exclusion. ${ }^{7}$ Conversely antrectomy, which evokes hypogastrinaemia, is associated with a decrease in the enterochromaffin like cell number. ${ }^{811}$

Although gastrin is known to stimulate mitosis in the epithelial stem cells of the oxyntic glands, ${ }^{12}$ its role as a trigger of the enterochromaffin like cell proliferation has been challenged. ${ }^{13} 14$ Enterochromaffin like cells, like chief cells, ${ }^{15}$ appear to be renewed through self replication rather than through differentiation from stem cells in the progenitor zone (in the isthmus of the glands)..$^{16}$ This might suggest that the enterochromaffin like cells, in analogy with the zymogen cells, ${ }^{15}$ do not respond to the mitogenic effect of gastrin.

The aim of this study was to evaluate the effects of antrectomy and antrum exclusion on the oxyntic mucosal cell kinetics with special reference to the enterochromaffin like cells. For this purpose, the enterochromaffin like cells were selectively stained by the use of histamine antibodies in combination with autoradiography after administration of tritiated thymidine.

\section{Methods}

\section{ANIMALS}

Eighteen male Sprague-Dawley rats (200-250 g body weight) were divided in three groups with six in each $(a, b$, and $c)$. They had free access to standard food pellets and tap water throughout the study.

In group a, an antrectomy was carried out by resecting the distal half of the glandular stomach, including the duodenal bulb, followed by endto-end gastroduodenostomy. In group $b$, antrum exclusion was performed by transecting the stomach between the oxyntic and antral mucosa and resecting $3 \mathrm{~mm}$ of the antral margin to eliminate all acid producing cells from the antral remnant. The gastrointestinal continuity was reestablished by an end-to-side gastrojejunostomy. In group c, a sham operation (laparotomy) was done.

After six weeks, the animals were killed by exsanguination under ether anaesthesia between 10 and $11 \mathrm{am}$, one hour after an ip injection of ${ }^{3} \mathrm{H}$-thymidine $(10 \mathrm{Ci} / \mathrm{mmol}$, IRE, Fleurus, Belgium) at a dose of $1 \mathrm{mCi} / \mathrm{kg}$ body weight. Blood was drawn from the abdominal aorta. Serum was stored at $-25^{\circ} \mathrm{C}$ until assayed for gastrin.

The stomach was resected, opened along the greater curvature, rinsed in saline and pinned on a wooden plate with the mucosa upwards. Tissue specimens, $5 \mathrm{~mm}$ in diameter, were taken from the midportion of the oxyntic gland area on the anterior stomach wall. The specimens were frozen in a propane/propylane mixture at the temperature of liquid nitrogen and freeze dried at $-86^{\circ} \mathrm{C}$. The freeze-dried specimens were fixed in diethylpyrocarbonate vapour (three hours at $55^{\circ} \mathrm{C}$ ) and embedded in Epon 812 . One micrometer thick transverse sections were cut perpendicular to the mucosal surface, with the whole mucosal thickness included. Care was taken to leave at least $10 \mu \mathrm{m}$ interspace between the sections so that the same cell nucleus does not appear in more than one section. 
with antibodies to histamine (no 8431 , Milab, Malmö, Sweden ${ }^{18}$ using the peroxidase-antiperoxidase (PAP) procedure..$^{19}$ The sections were treated with $1 \%$ potassium hydroxide in $96 \%$ ethanol for 15 minutes to remove the resin. The sections were then exposed overnight to the histamine antiserum (diluted 1:6000 in phosphate buffered saline, PBS) in a moist chamber at room temperature. After rinsing in PBS, the sections were incubated at $20^{\circ} \mathrm{C}$ for two hours with goat-antirabbit IgG (1:80 in PBS, Milab) and rinsed again. They were then incubated with the PAP complex (1:160 in PBS, Dakopatts, Copenhagen, Denmark). After rinsing, the sections were stained for peroxidase. ${ }^{19}$ Sections incubated with the histamine antiserum preabsorbed with histamine (Sigma, St Louis, MO, USA) at a concentration of $50 \mathrm{mmol}$ served as controls. This pretreatment prevented the immunostaining. To evaluate the enterochromaffin like cell density we counted the number of enterochromaffin like cells with a clearly visible nucleus in $1 \mu \mathrm{m}$ thick sections spanning $1 \mathrm{~cm}$ of full thickness mucosa in each animal (objective, $\times 10$; magnification, $\times 160$ ).

DETERMINATION OF ENTEROCHROMAFFIN LIKE CELL LABELLING INDEX

After the enterochromaffin like cells had been stained as above, the sections were dried in air and covered in vacuo with a thin carbon layer to prevent chemographic reactions. They were then exposed to a nuclear emulsion (Ilford K5, Ilford $\mathrm{Co}, \mathrm{UK}$ ) for 26 days at $4^{\circ} \mathrm{C}$ and developed in Dektol (Kodak Dektol Developer, Eastman Kodak, Rochester, NY, USA). The labelling index - that is, the percentage of enterochromaffin like cells that were radioactively labelled, was calculated from the examination of at least 500 enterochromaffin like cells per animal (objective $\times 63$, magnification $\times 630$ ). Only enterochromaffin like cells with a visible nucleus

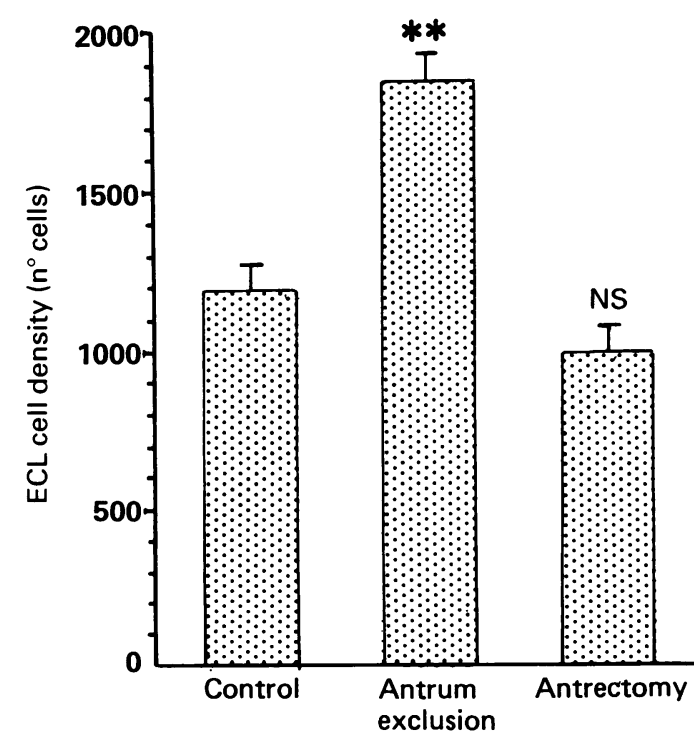

Figure 1: Enterochromaffin like cell density (number of enterochromaffin like cells in the mucosal volume under $0.01 \mathrm{~mm}^{2}$ of mucosal surface) in control rats and after antrum exclusion or antrectomy.

${ }_{\star \star} p<0 \cdot 01 . N S=$ not significant. surrounded by immunostained cytoplasm were taken into account. Cells were considered labelled when four or more silver grains were found over the nucleus. The position of each labelled enterochromaffin like cell in the mucosa was noted. For this purpose. the glands were subdivided in three parts (lower, middle, and upper third). In addition, in order to see mitotic figures, sections from all animals stained for histamine were counterstained with haematoxylin.

DETERMINATION OF LABELLING INDEX IN STEM CELLS

The sections were first subjected to the autoradiography (as above) and then stained with toluidine blue. The labelling index of the epithelial stem cells - that is, the percentage of labelled cells (excluding the parietal cells) in the area of maximal proliferation or 'progenitor zone' of the oxyntic glands, was estimated in 20 well orientated glands per rat. The progenitor zone was defined as the area between the uppermost chief cell and the uppermost parietal cell in each gland. ${ }^{15} 16$ Cells were considered labelled when at least four grains were found over the nucleus. The mean background labelling was always less than 1 grain $/ 100 \mu \mathrm{m}^{2}$ of mucosal tissue.

\section{SERUM GASTRIN DETERMINATION}

Serum gastrin was determined by radioimmunoassay as described previously. ${ }^{20}$ The concentration was expressed as equivalents of synthetic human gastrin I.

\section{STATISTICAL ANALYSIS}

All values are expressed as mean (SEM). Groups were compared using two tailed Student's $t$ test after arcsine transformation of the percentages or Mann Whitney U-test whenever appropriate.

\section{Results}

ENTEROCHROMAFFIN LIKE CELL DENSITY The enterochromaffin like cell density increased by $52 \%$ following antrum exclusion (Fig 1). In the antrectomised rats, the enterochromaffin like cell density did not decrease significantly $(-17 \%)(0.05<\mathrm{p}<0 \cdot 10)($ Fig 1$)$.

\section{ENTEROCHROMAFFIN LIKE CELL}

PROLIFERATION

In control rats $0.47 \%(0.05)$ of the enterochromaffin like cells were labelled. In the antrum excluded group, the labelling index had increased to $0.97 \%(0.20)(p<0.05)$ whereas antrectomised rats had a much lower labelling index - that is, $0.11 \%(0.05)(\mathrm{p}<0.01)$ (Fig 2). In all three groups, two thirds of the labelled enterochromaffin like cells occurred in the basal third of the glands. A few mitotic figures were observed in enterochromaffin like cells in the antrum excluded rats but not in the other groups. 


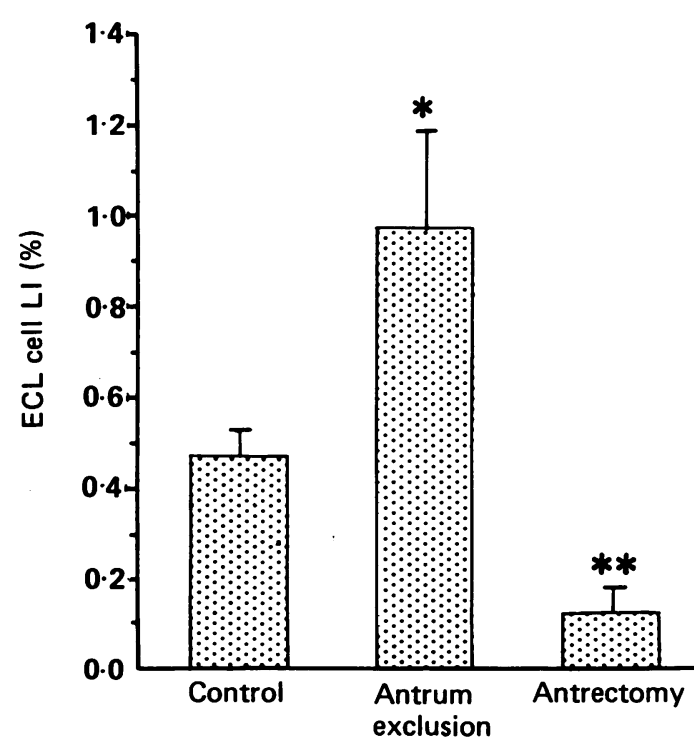

Figure 2: Enterochromaffin like cell labelling index in control rats and after antrum exclusion or antrectomy. ${ }^{\star} p<0.05 . \star \star=p<0.01$.

EPITHELIAL STEM CELL PROLIFERATION The labelling index of the stem cells in the progenitor zone of the oxyntic glands was $9 \cdot 45 \%$ $(0.29)$ in the control rats. After antrum exclusion, this labelling index reached $11 \cdot 29 \%(0 \cdot 38)$ $(\mathrm{p}<0.01)$ (Fig 3). Conversely, antrectomy decreased the labelling index to $7 \cdot 70 \%(0 \cdot 24)$ $(\mathrm{p}<0 \cdot 01)$ (Fig 3).

\section{SERUM GASTRIN CONCENTRATION}

In control rats, the serum gastrin concentration was $245(80) \mathrm{pg} / \mathrm{ml}$. Antrum exclusion nearly doubled the serum gastrin concentration (Fig 4). In the antrectomised rats, the concentration dropped to less than $25 \%$ of the control value (Fig 4). There was a good correlation between the serum gastrin concentration and the labelling index of the enterochromaffin like cells (Fig 5) as well as of the stem cells (Fig 6).

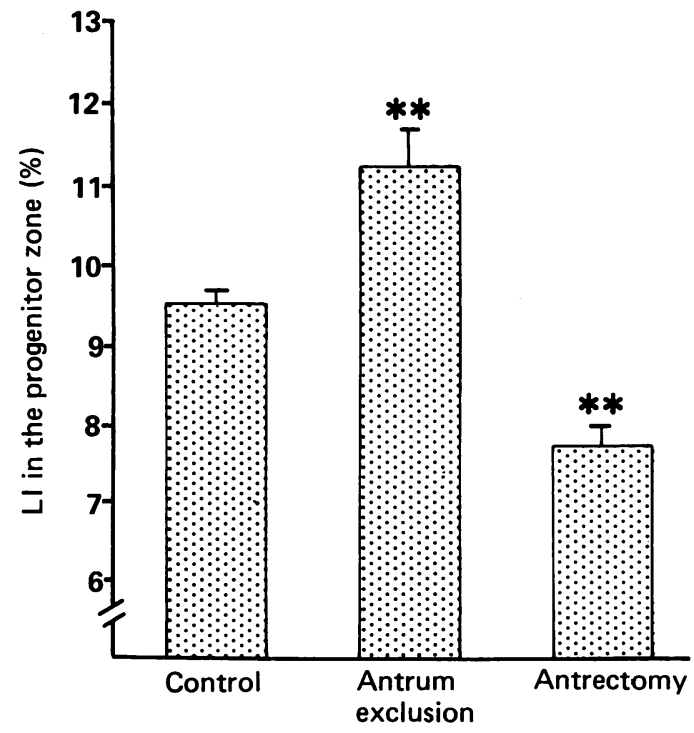

Figure 3: Labelling index of stem cells in the progenitor zone of the oxyntic glands in control rats and after antrum exclusion or antrectomy. ${ }_{\star \star}$ or antrectomy.

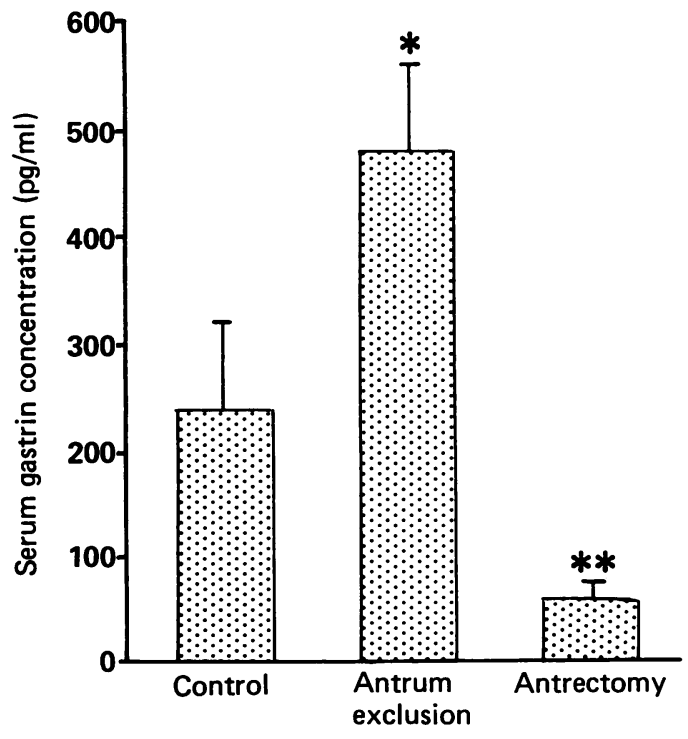

Figure 4: Serum gastrin concentration in control rats and after antrum exclusion or antrectomy. ${ }^{\star} p<0.05 .{ }^{\star}=p<0.01$.

\section{Discussion}

The enterochromaffin like cells, which form the major endocrine cell population in the oxyntic mucosa ${ }^{21-23}$ seem to be the only epithelial cells in the glandular stomach of the rat that contain histamine ${ }^{2425}$ Mast cells are very few and have an extra epithelial localisation. Hence, the cytokinetics of the enterochromaffin like cells can be studied by combining histamine immunohistochemistry and autoradiography after ${ }^{3} \mathrm{H}$-thymidine administration. ${ }^{16} 17$ The enterochromaffin like cells are thought to be renewed through self replication rather than through differentiation from stem cells. ${ }^{17}$ Many, but not all, endocrine cells in the gastrointestinal tract are capable of self replication. ${ }^{26-32}$ Although no mitotic figures were observed in the enterochromaffin like cells of control rats, a few of them were found to incorporate ${ }^{3} \mathrm{H}$-thymidine thus confirming previous observations that entero-

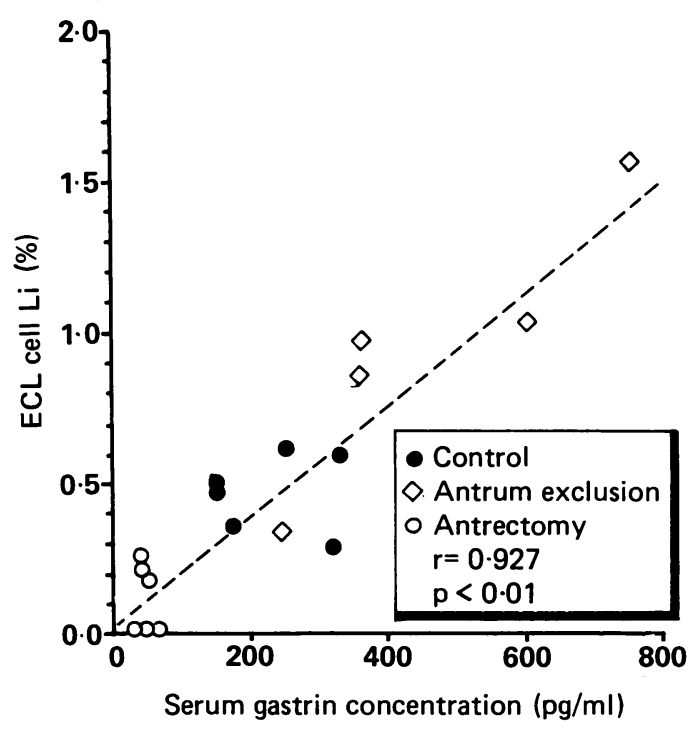

Figure 5: Enterochromaffin like cell labelling index $(L I)$ as a function of the serum gastrin concentration at the time of death. There was a positive correlation $(r=0.927)(p<0.01)$ between the $L I$ and the serum gastrin concentration. 


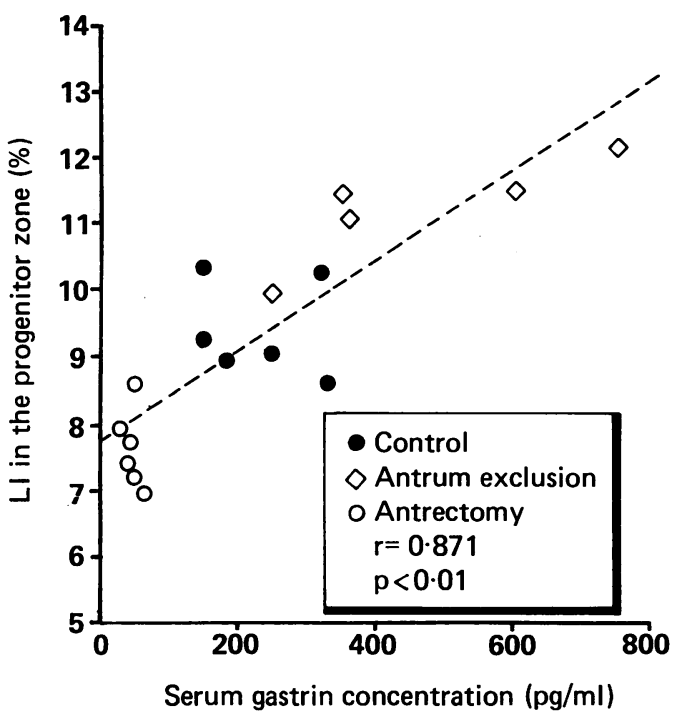

Figure 6: Labelling index (LI) of stem cells in the progenitor zone of the oxyntic glands as a function of the serum gastrin concentration at the time of death. There was a positive correlation $(r=0.871)(p<0.01)$ between the LI and the serum gastrin concentration.

chromaffin like cells are able to divide. ${ }^{17}$ Most labelled enterochromaffin like cells were seen in the basal parts of the oxyntic glands, far from the isthmus where the epithelial stem cells are located. ${ }^{12}$ is The lack of labelled enterochromaffin like cells in the progenitor zone suggests that they proliferate independently of the epithelial stem cells.

Our data show that antrum exclusion raised the serum gastrin concentration and enhanced the proliferation rate of the enterochromaffin like cells. The labelling index of these cells had doubled and a few mitotic figures could be observed in enterochromaffin like cells. Because of the extremely slow turnover of enterochromaffin like cells under basal conditions ${ }^{17}$ and the very short duration of the mitotic phase, mitoses are rarely seen in enterochromaffin like cells in normal oxyntic glands. The increase in the enterochromaffin like cell proliferative parameters was accompanied by a significant increase in the enterochromaffin like cell density. Although it cannot be excluded that a prolonged life span or an increased differentiation rate from stem cells also may account for the enterochromaffin like cell hyperplasia, it seems more likely that it is the result of stimulation of the enterochromaffin like cell self replication. In fact, an analogous increase in the self replication rate of the enterochromaffin like cells was observed after the administration of high doses of omeprazole, which also raised the serum gastrin concentration. ${ }^{16}$

Six weeks after antrectomy, the enterochromaffin like cell labelling index had decreased to less than $25 \%$ of the control value. At this time, however, the enterochromaffin like cell density was not significantly reduced. Other authors have noticed a significant decrease in the enterochromaffin like cell number after antrectomy after a postoperative time interval of eight to 10 weeks. ${ }^{83}$ These observations, and the previous finding that a long time interval (between 10 and 20 weeks) is needed for the enterochromaffin like cell number to normalise after stopping the administration of omeprazole, ${ }^{10}$ suggests that the enterochromaffin like cells have a long life span. Our data showed a good correlation between the serum gastrin concentration and the enterochromaffin like cell labelling index. A similar correlation was observed after administration of omeprazole. ${ }^{16}$ These observations favour the hypothesis that endogenous gastrin is indeed capable of influencing the enterochromaffin like cell self replication rate. This hypothesis is compatible with the results of a recent study in which continuous infusion of a synthetic analogue of human gastrin-17 (leu's -gastrin-17) was found to increase the enterochromaffin like cell density. ${ }^{3+}$ Gastrin appears to have a mitotic effect not only on enterochromaffin like cells but also on the epithelial stem cells. ${ }^{12}$ is In the present study, the labelling index in the oxyntic mucosal progenitor zone was also found to be well correlated to the serum gastrin concentration. The relative increase in the labelling index in response to gastrin was greater in the enterochromaffin like cells than in the stem cells. The latter difference confirmed previous observations of a high sensitivity of enterochromaffin like cells to the mitogenic effect of gastrin in rats receiving omeprazole. ${ }^{16}$

This study was supported by grants from the Swedish MRC (04X-1007 and 04X-4499), Påhlsson's Foundation and AB Hässle. $Y$ Tielemans has a fellowship from the Swedish Institute and was supported by the 'Fonds voor Geneeskundig Wetenschappelijk Onderzoek' of Belgium.

1 Wilander E. Achylia. Pernicious anaemia, ECL cells and gastric carcinoids. Virchows Arch [A] 1980; 387: 371-3.

2 Bordi C, Pilato FP, Carfagna G, et al. Argyrophyl cell hyperplasia of fundic mucosa in patients with chronic hyperplasia of fundic mucosa in patients with chr

3 Borch K, Renvall H, Liedberg G, Andersen BN. Relations between circulating gastrin and endocrine cell proliferation in the atrophic fundic gastric mucosa. Scand $\mathcal{F}$ Gastroentero 1986; $21: 357-63$.

4 Rode J, Dhillon AP, Papadaki K, et al. Pernicious anaemia and mucosal endocrine cell proliferation of the non antral stomach. Gut 1986; 27: 789-98.

5 Bordi C, Cocconi G, Togni R, Vezzadini P, Missale G. Gastric endocrine cell proliferation. Association with ZollingerEllison syndrome. Arch Pathol 1974; 98: 274-9.

6 Bordi C, D'Adda T, Pilato FP, Ferrari C. Carcinoid (ECL cell) tumor of the oxyntic mucosa of the stomach: a hormone dependent neoplasm? In: Fenoglio-Preiser C, Wolff M, Rilke F, eds. Progress in surgical pathology. Philadelphia: Field and Wood, 1988; 8: 177-95.

7 Alumets J, El Munshid HA, Håkanson R, et al. Effect of alumets $\mathrm{J}$, El Munshid HA, Hăkanson $\mathrm{R}$, et al. Effect of
antrum exclusion on endocrine cells of a rat stomach. antrum exclusion on endocrir

8 Larsson $\mathrm{H}$, Carlsson E, Mattsson $\mathrm{H}$, et al. Plasma gastrin and gastric enterochromaffinlike cell activation and proliferation. Gastroenterology 1986; 90: 391-9.

9 Håkanson R, Böttcher G, Sundler F, Vallgren S. Activation and proliferation of gastrin cells and ECL cells in the stomach. Digestion 1986; 35 [suppl 1]: 23-41.

10 Larsson $\mathrm{H}$, Carlsson $\mathrm{E}$, Håkanson $\mathrm{R}$, et al. Time course of development and reversal of gastric endocrine cell hyperplasia after inhibition of acid secretion. Gastroenterology 1988; 95: 1477-86.

11 Håkanson R, Larsson L-I, Liedberg G, Oscarson J, Sundler $F$, Vang J. Effects of antrectomy or porta-caval shunting on the histamine-storing endocrine-like cells in oxyntic mucosa the histamine-storing endocrine-like cells in oxyntic mucosa of rat stomach. A fluorescence histochemical, electron
microscopic and chemical study. 7 Physiol 1979; 259: microscopic

12 Willems G, Vansteenkiste Y, Limbosch M. Stimulating effect of gastrin on cell proliferation kinetics in canine fundic mucosa. Gastroenterology 1972; 62: 583-9.

13 Penston J, Wormsley KG. Achlorhydria: hypergastrinemia carcinoids - a flawed hypothesis. Gut 1987; 28: 488-505.

14 Wormsley KG. Is chronic long-term inhibition of gastric secretion really dangerous? Scand $\mathcal{F}$ Gastroenterol 1988; 23 [suppl 146]: 166-74

15 Willems G, Lehy $\mathrm{T}$. Radioautographic and quantitative studies on parietal and peptic cell kinetics in the mouse. A selective effect of gastrin on parietal cell proliferation. Gastroenterology 1975; 69: 416-26.

16 Tielemans $Y$, Hăkanson $R$, Sundler F, Willems G. Proliferation of enterochromaffinlike cells in omeprazole treated hypergastrinemic rats. Gastroenterology 1989; 96: 723-9.

17 Tielemans Y, Sundler F, Håkanson R, Willems G. Combination of enterochromaffin like cell immuno-staining and 
autoradiography in the mouse stomach. $\mathcal{F}$ Histochem Cytochem 1988; 36: 935

18 Håkanson R, Böttcher G, Ekblad E, et al. Histamine in endocrine cells in the stomach. A survey of several species using a panel of histamine antibodies. Histochemistry 1986 86: 5-17.

19 Sternberger LA. The unlabelled antibody peroxidaseantiperoxidase (PAP) method. In: Sternberger LA, ed. Immunocytochemistry 2nd ed. New York: John Wiley \& Sons, 1979: 104-70

20 Stadil F, Rehfeld JF. Determination of gastrin in serum. An evaluation of the reliability of a radioimmunoassay. Scand Gastroenterol 1973; 8: 101-12.

21 Håkanson R, Owman C, Sporrong B, Sundler F. Electron microscopic identification of the histamine-storing argyrophil (enterochromaffin-like) cells in the rat stomach. Z Zellforsch 1971; 122: 460-6.

22 Capella C, Vassallo G, Solcia E. Light and electron microscopic identification of the histamine-storing argyrophil (ECL) cell in murine stomach and of its equivalent in other mammals. Z Zellforsch 1971; 118: 68-84.

23 D'Adda T, Bertelé A, Pilato FP, Bordi C. Quantitative electron microscopy of endocrine cells in oxyntic mucosa of normal human stomach. Cell Tissue Res 1989; 255: 41-8.

24 Rubin W, Schwartz B. Electron microscopic radioautographic identification of the ECL cells as the histamine-synthesizing endocrine cell in the rat stomach. Gastroenterology 1979; 77: 458-67.

25 Kubota H, Taguchi Y, Tohyama M, et al. Electron microscopic identification of histidine decarboxylase-containing endocrine cells of the rat gastric mucosa: an immunohistochemical analysis. Gastroenterology 1984; 87: 496-502.

26 Lehy T, Willems G. Population kinetics of antral gastrin cells in the mouse. Gastroenterology 1976; 71: 614-9.

27 Fujimoto S, Hattori T, Kimoto K, Yamashita S, Fujita S, Kawai K. Tritiated thymidine autoradiographic study on origin and renewal of gastrin cells in antral area of hamsters. origin and renewal of gastrin cells in
Gastroenterology 1980; 79: 785-91.

28 Lehy T. Self replication of somatostatin cells in the antral mucosa of rodents. Cell Tissue Kinet 1982; 15: 495-505.

29 Deschner E, Lipkin M. An autoradiographic study of the renewal of argentaffin cells in human rectal mucosa. Exp Cell Res 1966; 43: 661-5.

30 Odartchenko $\mathbf{N}$. Cytokinetics of argentaffin cells in mouse intestinal mucosa. Virchows Arch B 1970; 6: 132-6.

31 Hattori T, Niki S, Fujita S. Tritiated thymidine autoradiographic study on the origin and renewal of argentaffin cells in the pyloric gland of hamsters. Cell Tissue Res 1977; 181: the py.

32 Inokuchi $H$, Fujimoto $S$, Hattori $T$, Kawai $K$. Tritiated thymidine radioautographic study on the origin and renewal thymidine radioautographic study on the origin and renewal
of secretin cells in the rat duodenum. Gastroenterology 1985 ; of secretin cells

33 Axelson J, Ekelund M, Sundler F, Håkanson R. Gastrin and the vagus interact in the trophic control of the rat oxyntic mucosa. Regul Pept 1988; 22: 237-43.

34 Ryberg B, Axelson J, Håkanson R, Sundler F, Mattsson H. Trophic effects of continuous infusion of (Leu's) - Gastrin 17 in the rat gastroenterology 1990 (In press). 